\title{
SERENDIPITY AND THE MORNING CHRONICLE 1819
}

\author{
Major-General F. M. RICHARDSON, \\ C.B., D.S.O., O.B.E., M.D., Late R.A.M.C. (Retd.)
}

SERENDIPITY, that splendid word coined in 1754 by Horace Walpole, means finding something nice when you are looking for something different. Chambers Etymological Dictionary, defining it as 'the faculty of making happy chance finds ' says it was derived from the title of a fairy tale "The Three Princes of Serendip ", an old name for Ceylon. These Princes "were always making discoveries by accident and sagacity, of things they were not in quest of '.

If life were long enough a lot of fun could be got from serendipping in the fascinating bran-tub of old newspapers. Some time ago, whilst searching through 'The Morning Chronicle' of 1819 for comments on our treatment of Napoleon in St. Helena, my eye was momentarily caught by a headline (6th January 1819) "Daring Outrage in Edinburgh "; and would have passed on but for catching sight of a significant surname -Porteous. Being a descendant of Captain William Richardson of Gilmerton, appointed on 21 April 1704 to be second in command of our ' good tounes Companie of Granadeirs ', equivalent, I like to think, to Assistant Chief Constable, I have always taken an interest in the terrible fate of one of his successors, poor Captain Porteous, hanged by a mob in horrible circumstances excitingly related by Sir Tresham Lever in Blackwoods Magazine'.

Here in 1819 was another Porteous involved in a gruesome hanging, this time not as the victim but as chaplain to the Jail. The Reverend Mr. Porteous was a member of the platform party at a horribly bungled execution-the hanging, on a platform erected in the Lawnmarket in front of the New County Hall, of Robert Johnston, ' a strong, stout good-looking man between 20 and 30 '. The son of respectable shopkeeping parents, he had been of good character until, through consorting with evil companions, he sank to the 'street robbery of a candle-maker'. Robert had accepted the justice of his fate with resignation, until appalling circumstances led him to fight for his life through the hour of it which unexpectedly remained to him. The executioner began his job, and ' a painful and disgraceful scene immediately ensued. The rope was observed to be too long for the fall of the drop, and the unfortunate culprit rested with his toes on the platform '.

Carpenters had begun to cut away the platform, in order that the sufferer might as speedily as possible be relieved, when the crowd, who had expected a reprieve, took a hand. Shouting "Murder" they rained stones upon the officers of the law so effectively that in a minute only poor Robert, still on tiptoe, was left on the scaffold. The rest had fled for shelter, first to the porch of the Tolbooth Church adjacent to the Writers' Library, and thence, via the aisle of the High Church, to the Police Office. The victim after hanging for some five minutes was cut down by a respectably dressed gentleman, the cap was removed from his face and he partially revived. Several policemen had been hurt, the hangman suffered severely, and the coffin awaiting the hanged man's body was smashed and hurled through the church windows. Robert's parents were quickly in-

\footnotetext{
'Lever, Sir Tresham. "Sir Walter Scott and the Murder of Porteous". Blackwoods Magazine. Vol. 310. Pp. 212-224.
} 
formed that he had escaped, but when this later proved to be a false hope his mother went out of her mind.

The magistrates rallied the forces of law and order, brought down from the Castle a detachment of the 88th Foot (Connaught Rangers) and recaptured the scaffold and. their victim - what a job for one of Wellington's fiercest fighting regiments. Now the bungling could begin again. Before a second attempt was started Robert had been bled from both arms and a temporal vein to determine if he was still alive (an unpleasant refinement for which the magistrates later denied responsibility). This time, as a later number of The Morning Chronicle pointed out with scandalised severity, Robert Johnston was naked and even his face was uncovered. The rope was still too long, but by holding up the body and taking several turns of the rope around the neck it was done at last, though Robert had got one hand free and clung to the rope for quite a time.

Edinburgh, perhaps with dim memories of Half-Hangit Maggie Dickson ${ }^{2}$, may have been hardened to such horrors, but the rest of the country turned savagely upon the incompetent magistrates and their servants, $\mathrm{Mr}$ Porteous must have been a popular minister for everyone seemed pleased that reports that he had been injured were untrue; but the sacking of the executioner gave general satisfaction.

The Caledonian Mercury of 4 January, attempting a spirited defence of the City fathers, blamed the mob for prolonging the culprit's suffering, which would have been speedily ended but for their unwarranted interference. The Morning Chronicle would have none of this and trumpeted that the magistrates had been far more blameworthy; and indeed this was the view of the Lord Advocate when the sickening proceedings were investigated by the High Court of Justiciary (My serendipitous luck held when I sought the facts about Margaret Dickson from Mrs. Margaret Mackay of the Edinburgh Library, whose encyclopaedic knowledge covered both the half-hangit culprits, and 'more much more, I promise you' as Michael Barratt says in Nationwide. She showed me a letter written on 1 January 1819, by one William MacBean to his mother in Tain. The first page and more of local Edinburgh gossip showed that the winter of 1819 was even milder than that of 1973-" flowers or even fruits are flourishing . . pears and apple trees are in full bloom. Pro-di-gi-ous". He went on to say that the city was "in a ferment on account of a 2nd edition of the Porteous mob" ).

Napoleon being done to death by the conditions in his prison-isle of St. Helena, more slowly, less horribly; but just as inexorably as Robert Johnston in the Lawnmarket, was now beginning to take second place in my mind to the awful fascination of these almost weekly public spectacles.

On 1st February the headline "Condemned Sermon" startled me into thinking how many dreary offerings I have condemned myself; but this one, of course, was "a suitable discourse ... delivered in Newgate Chapel by the Reverend Dr. Cotton to the three unfortunate men ordered for execution tomorrow morning. They are apparently

\footnotetext{
${ }^{2}$ Margaret Dickson, a young Musselburgh fishwife separated from her husband, had thrown her still-born baby into the Tweed, for which, under the Concealment of Pregnancy Act of 1690, she was hanged in the Grassmarket on 2 September 1724. Whilst her friends were taking her body away in a cart they had to beat off a determined assault by surgeon-apprentices, trying to snatch it for dissection. The coffin was smashed open, and whilst the carter was refreshing himself at the Peffermill Inn, Margaret showed signs of life. After a vein had been opened by one, Peter Purdie, she revived and was taken to her brother's home. As the certificate of execution had been signed, the magistrates had no further claim upon her. She remarried her former husband, bore him several children, and lived on for another 40 years, an object of pride to the citizenry, and indeed a tourist attraction-quite proud of her title "Half-Hangit Maggie Dickson".
} 
penitent and resigned to their melancholy fate". Melancholy-not perhaps quite the word one might choose--sparked off memories of a friend who visited an Indian prison. Stopping at one cell he said to his escort: " Jailer babu, your prisoners all look quite contented; except this poor fellow." "Sir, he is to be hanged tomorrow-therefore he is somewhat peevish".

But "melancholy" will do for the sensation with which one encounters these repeated descriptions of nineteenth century hangings. The mock piety with which the awful scenes are described thinly camouflages the gruesome relish. Last speeches of the condemned felons are patronisingly applauded, unless the doomed wretch had refused to confess his guilt. This was plainly considered to be extremely bad form. No doubt it slightly ruffed the self-righteous mood in which the spectators dispersed. The trivial offences which could earn the death penalty never fail to amaze and appal us. One young boy of 15 was in peril of a death sentence for what sounded like no more than associating with known criminals. In case we should feel too smug about our own more humane treatment of the young it might be noted that, although in 1819 the headline "Child Dropping" was often seen, the babies were only deposited on doorsteps, and so on. The Battered Baby Syndrome was not to be talked about until halfway through the twentieth century.

On one day in 1819 several persons, young and old, were sentenced to hang for 'privately stealing in a shop'. It might give quite a fillip to the unending debate about the death penalty to propose a trial period of death sentences as a possible deterrent to shoplifting.

Shoplifters in a modern supermarket would seek in vain for a richer haul than the one described on 23 February 1819, under the headline "Buttered Sovereigns". A Mr. J., having purchased a ' furkin of butter for his private use', found in it two hundred and twenty sovereigns, for which a bullion broker gave him £227.10.0. Not a clue was offered as to how they got there, a good subject for a "Who-dun-it"?

Still on executions, it was good to read that in the United States Indian prisoners were no longer to be executed without the President's approbation. It seemed that General Jackson's conduct in the Seminole War had not met with universal approbation. One wonders whether Messrs. Roosevelt and Dulles, casting disapproving eyes on our own poor old Colonial Empire, ever spared a thought for the Indian skeletons in their own cupboard, not forgetting, why should we?-Mexican Indians. Lord Palmerston's cynical comment that "Mexico was destined to be devoured by the Anglo-Saxon race before it disappeared altogether as the Redskins did before the white man ", may explain, though hardly condone, the grabbing by the United States between 1837 and 1849 of over a million and a half square miles of Mexican territory, including Texas, New Mexico and Southern California. Feelings about colonial expansion depend on who is expanding. That great naval explorer James Cook, cut down on his distant beach, met the just fate of a colonising expansionist; whilst General Custer, bristling with arrows like St. Sebastian, died a martyr to the sacred cause of the Westward spread of American civilisation. Perhaps the inhabitants of the sub-continent of India, whom we can no longer call simply Indians, have more causes for gratitude to their old oppressors than have the Indians of North America, or of Mexico. Pierre Salinger, reviewing Dee Brown's book "Bury my Heart at Wounded Knee", wrote that the United States" treatment of American Indians " ranks high in the list of History's attempted extinction 
of one race by another ", Those who view our colonial past through Roosevelt-Dullestinted glasses might well repeat daily those poignant words ' Bury my Heart at Wounded Knee '. At least we have not flooded the world with 'Easterns' to match all those epic 'Westerns', differing from one another chiefly in the names of the tribes whose Indians bite the dust on television screens, week after weary week.

Turning the pages through the Summer of 1819, a sense of foreboding arose from the foreknowledge that on 16th August the magistrates of Manchester had perpetrated a blunder of which the consequences far exceeded those of the bungled hanging in Edinburgh. This was the event which became known as 'Peterloo', when the timid magistrates, fearing that a speech by the famous 'Orator Hunt' would inflame the vast and essentially peaceable crowd of some 80,000 Reformers, ordered the police to arrest him. A detachment of yeomanry, probably ill-trained and ineptly led and certainly unaccustomed to duties in aid of the civil power, trying to help the police, got so jostled by the crowd that they lost their heads and slashed about with their sabres. The early reaction of Sir Walter Scott, himself an old yeomanry enthusiast, was that the yeomanry behaved well in dispersing so immense a crowd, without needless violence, whatever the papers said. Really Sir Walter, espirit-de-corps, the yeomanry spirit and all that-but sabres? For English yeomanry soldiers had been seen wiping the blood of Englishmen from their sabres; and eye-witness accounts left no doubt that the troopers had hacked their way through an unresisting crowd. The disaster divided the nation, and that by no means along party lines.

How would The Morning Chronicle react? On 22nd July they had reported a Smithfield Meeting for Reform, with speeches by Hunt, and in a reproving editorial had denounced the violence with which the Reformers thought they could force the Government to adopt such 'wild and impracticable measures' as. Universal Suffrage, Annual Parliaments, and Voting by Ballot. But surely among their customary columns. devoted to Boxing, Sparring, and the Mirror of Fashion they would find a place for a denunciation of the Manchester magistrates; so much more culpable than the bungling bailees of Auld Reekie. One can imagine the banner headlines of today; but that was not the manner of 1819 . On 27 August, the day after the disaster, it was reassuring to read that, in Scotland at least, all was quiet on the Western Front. The Glasgow.Weavers, who had been on strike because their wages had been reduced to one shilling a day, in consequence of the numbers who had applied for work, had accepted the situation and resumed work. On the $18 \mathrm{th}$, vague rumours of trouble; but on the 19 th three and a half columns of 'Private Letters' from Manchester and quotations from The Manchester Mercury revealed that something unusually terrible had occurred.

Thereafter not a day passed for months without stories of the many and varied repercussions of the massacre; explanations, justifications, Hunt's interrogation, reports of inquests on victims; rude notices stuck on the house of Lord Sidmouth, the Home Secretary; nervous local authorities arresting all sorts of people on suspicion; public meetings of protest; pained letters on the mishandling of the incident by the yeomanry, often from old yeomanry-men who felt confident that their own regiments would have done much better. A trumpeter of the Peterloo detachment, having been abused and roughly handled in his favourite pub, had declared in robust military terms appropriate to the time, that he would knock the block off anyone who hinted that he had done more than his duty. An innocent sentry outside a military establishment having been assaulted 
by a body of responsible citizens, a substantial reward was offered for information about his assailants. The word 'Peterloo' first appeared in poetical offerings, such as "The Bloody Field of Peterloo' (Monday 4th October).

The deterrent effect of the deplorable incident was soon apparent. On 18th September The Morning Chronicle carried a lengthy report about a large meeting held at Meikleriggs - Muir near Paisley, to discuss the Manchester Massacre. Two troops of 7th Hussars, parading at Trongate before trotting off to Paisley, were stoned; many street lamps were broken, but by the time the cavalry arrived, together with the 86th Regiment and some Horse Artillery, the crowd had dispersed-not surprisingly.

Meanwhile life went on; Our venerable and afflicted Sovereign entered on the sixtieth year of his reign on 25th October; and on 5th November the sighting of a sea serpent balls rebounded from its scales, and it seized around the middle the bold seaman who had fired them, and ' he was seen no more'.

From The Limerick Guardian came a report of the murder of a priest by 'nightly villains '; some of them work around the clock nowadays.

In addition to all this serendipitous matter I did find what I had expected. The Morning Chronicle, ever watchful for evidence of harsh treatment of the fallen Emperor, ever ready to castigate the Government, pointed out on 2nd April that the only two doctors to whose visits Napoleon would consent had been forced to leave the island as soon as he needed them; and solemnly warned the nation of the opprobrium it would incur if the prisoner were to die deprived of proper medical attention.

To end with a final serendipitious find - a challenger for the possession of the shortest signature to Mr. A. Zyw, the penultimate name in the Edinburgh Telephone Directory, emerged in Major By of the Royal Engineers, whose initials were not given (The Army List of 1819 settles it. His name was John: so J. By wins by a letter. By the way, he appeared in The Morning Chronicle because his wife had just produced Baby By).

\section{R.A.M.C. "DOCTOR ENTRY"}

The Responsibility for Medical Officer recruitment into the Royal Army Medical Corps has been delegated to Brigadier (Retd.) John Voller. For convenience the A.M.D.2e aspect of the Army Medical Directorate has been re-located at the Royal Army Medical College.

All enquiries relating to the entry of Medical Practitioners, Medical Students or potential medical students should be directed to:

Brigadier (Retd.) John J. Voller M.R.C.S., L.R.C.P., F.F.A.R.C.S., Regimental Headquarters, R.A.M.C., Royal Army Medical College, Millbank, London SW1P 4RJ

Telephone: GPO: 01-834-9060 and Army Network Ext. 342. 